\title{
Pyoderma gangrenosum with renal and splenic impairment - Case report ${ }^{*}$
}

Manifestação esplênica e renal do pioderma gangrenoso - Relato de caso

\author{
Luciana Rabelo de Carvalho ${ }^{1}$
}

\author{
Virgínia Vinha Zanuncio ${ }^{1}$
}

Bernardo Gontijo²

\begin{abstract}
Pyoderma gangrenosum is an uncommon and recurrent neutrophilic dermatosis of unknown cause. The lesions usually start as tender sterile papulopustules or erythematous nodules that undergo necrosis followed by ulceration. The lower limbs are most commonly affected and around half of the cases are associated with systemic disorders. Although rare, cases of pyoderma gangrenosum with extramucocutaneous sterile neutrophilic infiltrate have been reported, with the lungs being the most commonly affected organ. We report a case of pyoderma gangrenosum with splenic and renal impairment. Pyoderma gangrenosum should be considered a multisystemic disease with classic cutaneous manifestations and potential involvement of internal organs.
\end{abstract}

Keywords: Neutrophils; Pyoderma gangrenosum; Skin diseases; Ulcer

Resumo: Pioderma gangrenoso é uma dermatose neutrofílica incomum, recorrente e de etiologia desconhecida. As lesões geralmente se iniciam como papulopústulas estéreis ou nódulos eritematosos que sofrem necrose seguida de ulceração. Os membros inferiores são mais comumente afetados e quase a metade dos casos está associada a doenças sistêmicas. Apesar de raros, casos de pioderma gangrenoso com infiltrado neutrofílico estéril extramucocutâneo foram relatados e os pulmões são os órgãos mais comumente acometidos. Nós relatamos um caso de manifestação esplênica e renal do pioderma gangrenoso. Pioderma gangrenoso deve ser considerado doença multissistêmica com manifestações cutâneas clássicas e potencial envolvimento de órgãos internos.

Palavras-chave: Dermatopatias; Neutrófilos; Pioderma gangrenoso; Úlcera

\section{INTRODUCTION}

Pyoderma gangrenosum (PG) is a rare, recurrent, idiopathic, neutrophilic and inflammatory dermatosis that affects predominantly women between 20 and 50 years of age. The classic clinical presentation is sterile, tender follicular papulopustules or erythematous nodules that undergo necrosis and rapidly progress to ulceration with a purulent base and irregular and undermined borders. Bullous, pustular and superficial granulomatous variants are also described. In general, one of the clinical forms that can coexist in the same patient predominates, and the location of the lesions is variable, with preference for lower limbs. Due to the polymorphous nature of the skin lesions and a significant variation in laboratory and histopathologic findings, diagnosis of PG depends on a close clinicopathologic correlation. In around $50 \%$ of the cases an underlying systemic disease (usually inflammatory bowel disease, arthritis, vasculitis, lymphoma, leukemia, monoclonal gammopathy and other mieloproliferative disorders) can be detected. The pathergy phenomenon occurs in approximately $30 \%$ of patients with PG. ${ }^{1-5}$

Cases of PG with visceral involvement, with the presence of a sterile neutrophilic infiltrate in sites other than the skin and/or mucous membranes, are extremely rare ${ }^{6-10}$ We report a patient with PG with splenic and renal impairment.

\footnotetext{
Received on 15.01.2013.

Approved by the Advisory Board and accepted for publication on 27.03.2013.

* Work performed at the Dermatology Department of the Hospital das Clínicas, Federal University of Minas Gerais (HC-UFMG) - Belo Horizonte (MG), Brazil. Conflict of interest: None

Financial funding: None

Medical Residents, Dermatology Unit, Federal University of Minas Gerais Teaching Hospital (HC-UFMG) - Belo Horizonte (MG), Brazil.

MD, PhD. Associate Professor of Dermatology, Medical School, Federal University of Minas Gerais (UFMG) - Belo Horizonte (MG), Brazil.

(C2013 by Anais Brasileiros de Dermatologia
} 


\section{CASE REPORT}

A 22-year-old female patient was referred for evaluation of tender bullae and nodules on her lower limbs that rapidly progressed to ulcers with purulent and necrotic base and irregular and undermined borders (Figure 1). Lesions had been present for the previous four months and the patient also complained of fever $\left(38^{\circ} \mathrm{C}\right)$ and abdominal pain. Her medical history revealed a persistent anemia since childhood. On physical examination, splenomegaly and pallor of ocular mucosa were detected.

Clinical diagnosis of PG was corroborated by the histopathologic finding of a dermal lymphocytic and histiocytic infiltrate with some perivascular neutrophils and plasmocytes. Subcutaneous fat tissue was densely infiltrated with lymphocytes and histiocytes and numerous interlobular polymorphonuclear leukocytes (Figure 2). Gram stain and $\mathrm{KOH}$ examination of the ulcer discharge yielded negative results.

Laboratory workup showed a positive ANA (titer 1:160; nuclear, fine, speckled pattern) normocytic and normochromic anemia, low serum iron and high ferritin levels. Bone marrow aspiration displayed hypercellularity and $23 \%$ of sideroblasts, but no ringed sideroblast. Normal or negative exams included anti-SM, anti-Ro, anti-La, P-ANCA, C-ANCA, rheumatoid factor, antiphospholipid antibodies, cryoagglutinins, anti-HIV, hepatitis serology, blood and urine cultures, complement fractions $\mathrm{C} 3$ and C4.

Multiple splenic nodular structures were detected on abdominal US. MRI showed intrasplenic and subphrenic collections (Figure 3). Gram staining and bacterial culture of needle aspirated material from the spleen were negative (cold abscess).

Treatment with an association of corticosteroid, cyclosporine and sulfasalazine resulted in significant improvement (Figure 4). A control US detected reduction of the dimensions of both the spleen and intrasplenic collections.

Lesions recurred upon tapering of corticosteroid and withdrawal of cyclosporine. A second MRI detected intrasplenic and subdiaphragmatic collections and an altered sign on the right kidney upper pole (Figure 5). Gram staining and bacterial cultrure from material obtained by renal biopsy was negative. Histopathologic findings were consistent with PG adjacent to the renal parenchyma with a dense granular and mononuclear infiltrate, xanthomatous macrophages and a large area of necrosis (Figure 6).

\section{DISCUSSION}

Although not fully understood, PG pathogenesis involves abnormalities in both cell-mediated and humoral immunity and neutrophil and monocyte function. ${ }^{4}$ Half the cases are associated with systemic

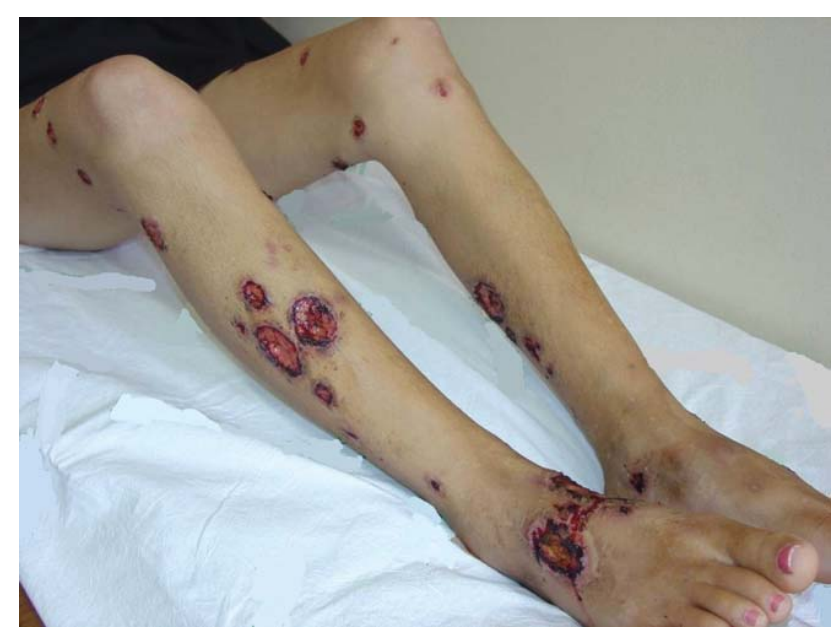

FIGURE 1: Ulcers with purulent and necrotic base and irregular and undermined borders
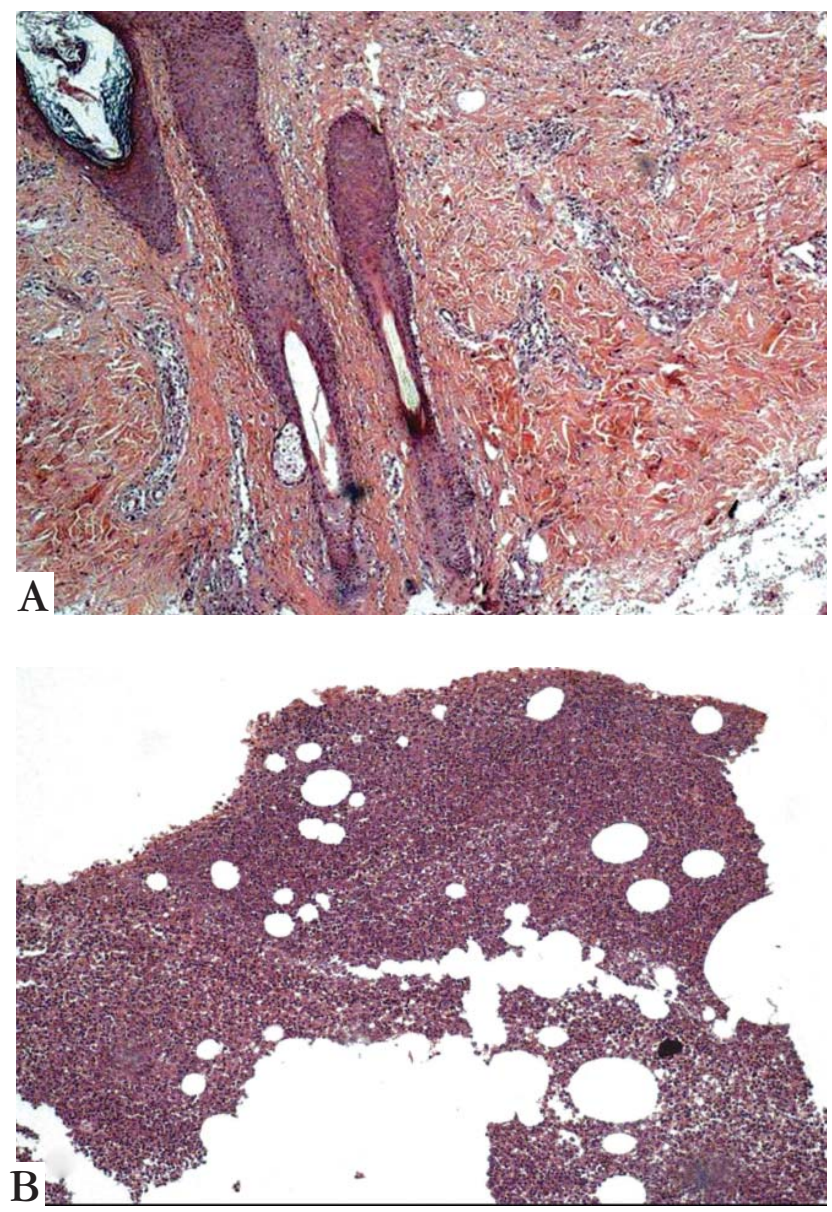

FIGURE 2: A and B. Dermal lymphocytic and histiocytic infiltrate with some perivascular neutrophils and plasmocytes. Subcutaneous fat tissue (2B) was densely infiltrated with lymphocytes and histiocytes and a large number of interlobular polymorphonuclear leukocytes 

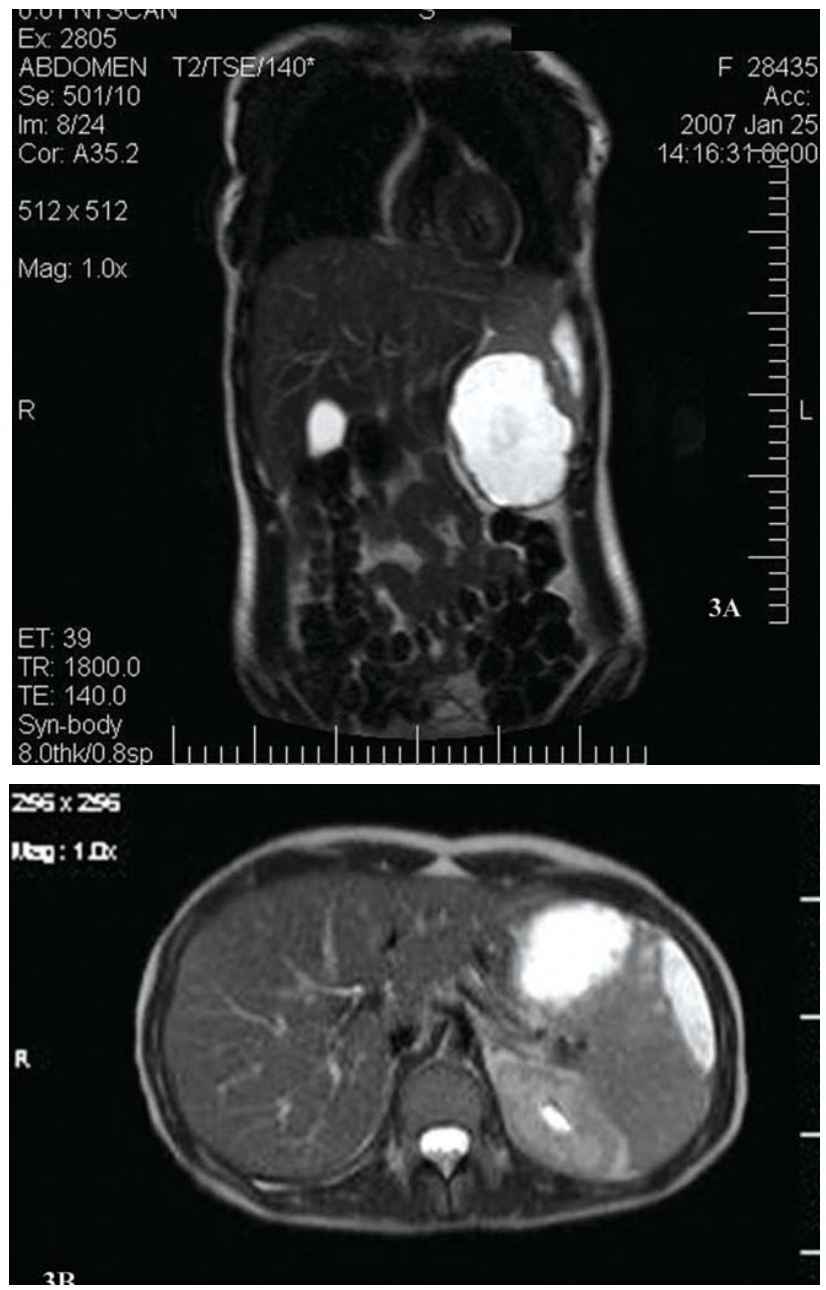

FiguRE 3: A and B. MRI showed intrasplenic and subphrenic collections

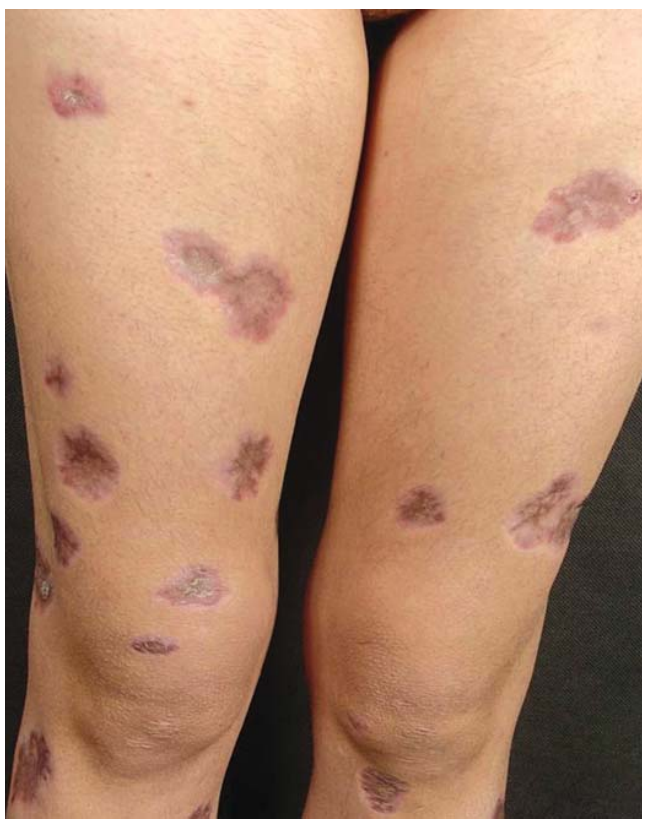

FiguRE 4

Skin lesions in healing process

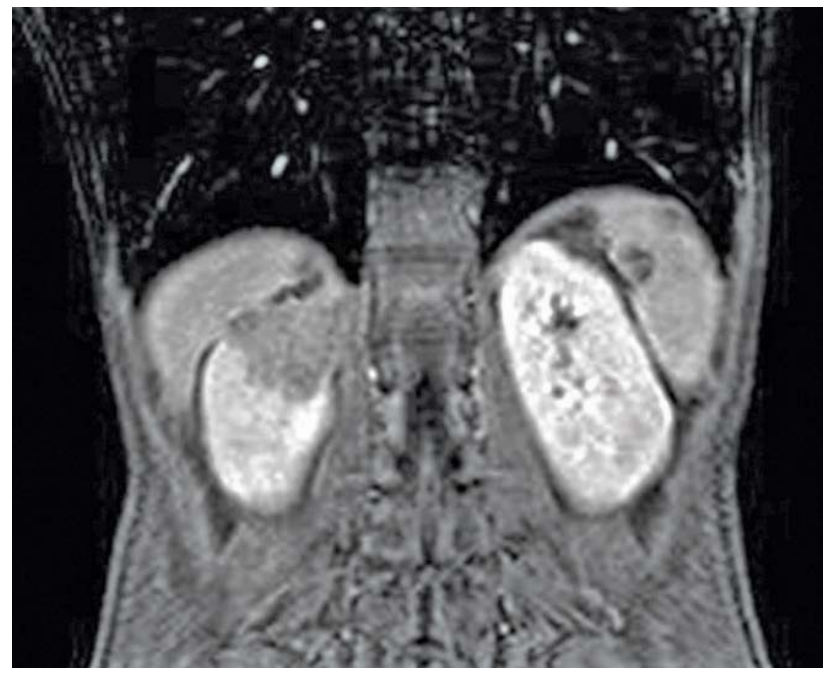

FIGURE 5: Altered sign on the right kidney upper pole
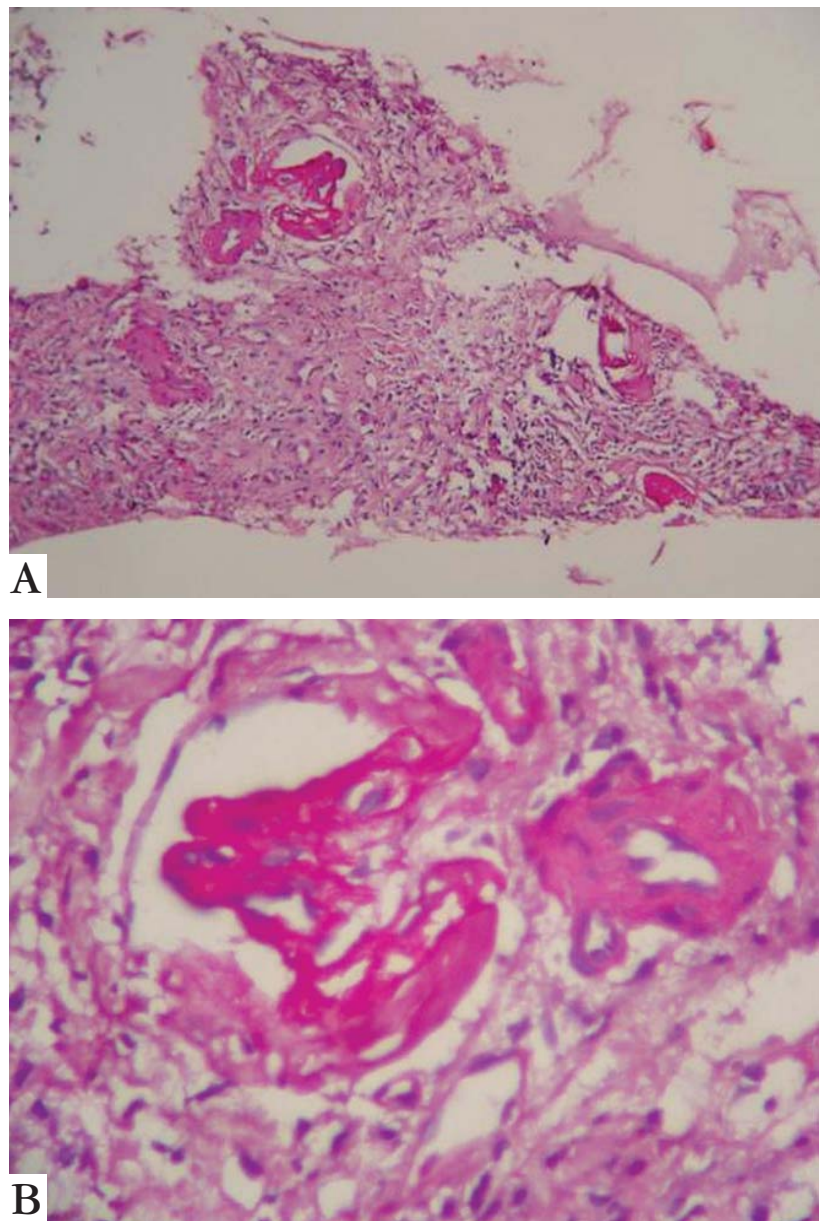

FIGURE 6: A and B. Histopathologic findings were consistent with PG adjacent to the renal parenchyma with a dense granular and mononuclear infiltrate, xanthomatous macrophages and a large area of necrosis 
diseases, most commonly autoimmune disorders. Pathergy is a phenomenon that occurs in about $30 \%$ of cases and is associated with dermal trauma, which may lead to the worsening of pre-existing lesions. ${ }^{1-5}$

Extramucocutaneous neutrophilic infiltrates are seldom seen in neutrophilic dermatoses. The lungs are the most frequently affected organ, but involvement of the heart, central nervous system, liver, spleen, lymphnodes, pancreas, joints, gastrointestinal tract and eyes has been reported..$^{6-10}$ Visceral involvement may be antecedent, coincident or subsequent to the skin lesions. ${ }^{8}$

Differential diagnosis should include infections, neoplasias, vasculitis, ulcers secondary to peripheral venous or arterial insufficiency and factitious dermatitis. Bacterial cultures are required to rule out infectious processes. ${ }^{5}$

\section{REFERENCES}

1. Binus AM, Qureshi AA, Li VW, Winterfield LS. Pyoderma gangrenosum: a retrospective review of patient characteristics, comorbidities and therapy in 103 patients. $\mathrm{Br} \mathrm{J}$ Dermatol. 2011;165:1244-50.

2. Crowson NA, MihmJr MC, Magro C. Pyoderma gangrenosum: a review. J Cutan Pathol. 2003;30:97-107.

3. Powell FC, Schroeter AL, Su WP, Perry HO. Pyoderma gangrenosum: a review of 86 patients. Q J Med. 1985;55:173-86.

4. Powell FC, Su WP, Perry HO. Pyoderma gangrenosum: classification and management. J Am Acad Dermatol. 1996;34:395-409.

5. Callen J P. Pyoderma gangrenosum. Lancet. 1998;351:581-5.

6. Poiraud C, Gagey-Caron V, Barbarot S, Durant C, Ayari S, Stalder JF. Cutaneous, mucosal and systemic pyoderma gangrenosum. Ann Dermatol Venereol. 2010;137:212-15.

7. Brahimi N, Maubec E, Boccara O, Marinho E, Valeyrie-Allanore L, Lecaille C, et al. Pyoderma gangrenosum with aseptic spleen abscess. Ann Dermatol Venereol. 2009;136:46-9.

8. Vadillo M, Jucgla A, Podzamczer D, Rufi G, Domingo A. Pyoderma gangrenosum with liver, spleen and bone involvement in a patient with chronic myelomonocytic leukaemia. Br J Dermatol.. 1999;141:541-3.

9. Bittencourt Mde J, Soares LF, Lobato LS, Mançano AD, Leandro HS, Fonseca DM. Multiple cavitary pulmonary nodules in association with pyoderma gangrenosum Case report. An Bras Dermatol. 2012;87:301-4.

10. Brown TS, Marshall GS, Callen JP. Cavitating pulmonary infiltrate in an adolescent with pyoderma gangrenosum: A rarely recognized extracutaneous manifestation of a neutrophilic dermatosis. J Am Acad Dermatol. 2000;43:108-12.
In the case reported here the cold abscesses of the spleen were initially considered as an associated disorder likely to have triggered PG. Later on, with renal biopsy displaying histopathologic changes compatible with PG, the authors considered the possibility that both spleen and renal lesions could be regarded as a visceral manifestation of PG. Although spleen biopsy was not performed, the striking improvement of the splenic lesions after treatment of the skin ulcers favors this hypothesis.

PG should be approached as a multisystemic disease frequently associated with an underlying internal disorder. PG involvement is primarily cutaneous but with potential visceral extension.

\author{
MAILING ADDRESS: \\ Anexo Osvaldo Costa (Dermatologia) \\ Alameda Álvaro Celso, 155 - Santa Efigênia \\ 30130-100 - Belo Horizonte - MG \\ Brazil \\ E-mail: adermato@hc.ufmg.br \\ Luciana Rabelo de Carvalho \\ SHIGS 705 Bloco R casa 04 - Asa Sul \\ 70350-718, Brasília - DF \\ Brazil \\ E-mail:lucianarcv@gmail.com
}

How to cite this article: Carvalho LR, Zanuncio VV, Gontijo B. Pyoderma gangrenosum with renal and splenic impairment- Case report. An Bras Dermatol. 2013;88(6 Suppl 1):S150-3. 